\title{
Characterisation of three novel $\beta-1,3$ glucanases from the medically important house dust mite Dermatophagoides pteronyssinus (airmid)
}

\author{
Rose Waldron $^{\mathrm{a}, \mathrm{b}}$, Jamie McGowan ${ }^{\mathrm{a}, \mathrm{c}}$, Natasha Gordon ${ }^{\mathrm{b}}$, E. Bruce Mitchell ${ }^{\mathrm{b}}$, \\ David A. Fitzpatrick ${ }^{\mathrm{a}, \mathrm{c}}$, Sean Doyle ${ }^{\mathrm{a}, *}$ \\ ${ }^{a}$ Department of Biology, Maynooth University, Maynooth, Co. Kildare, Ireland \\ ${ }^{\mathrm{b}}$ Airmid Healthgroup Ltd., Trinity Enterprise Campus, Dublin, Ireland \\ ${ }^{\mathrm{c}}$ Human Health Research Institute, Maynooth University, Maynooth, Co. Kildare, Ireland
}

\section{A R T I C L E I N F O}

\section{Keywords:}

$\beta-1,3$ glucanase

Enzyme

House dust mite

Yeast

D. pteronyssinus

Quantitative proteomics

Phylogenetics

\begin{abstract}
A B S T R A C T
The European house dust mite, Dermatophagoides pteronyssinus is a major source of airborne allergens worldwide and is found in half of European homes. Interactions between microbes and house dust mites (HDM) are considered important factors that allow them to persist in the home. Laboratory studies indicate the European HDM, D. pteronyssinus is a mycophagous mite, capable of utilising a variety of fungi for nutrients, however specific mycolytic digestive enzymes are unknown. Our previous work identified a number of putative glycosyl hydrolases present in the predicted proteome of $D$. pteronyssinus airmid and validated the expression of 42 of these. Of note, three GH16 proteins with predicted $\beta-1,3$ glucanase activity were found to be consistently present in the mite body and excretome. Here, we performed an extensive bioinformatic, proteomic and biochemical study to characterize three-novel $\beta-1,3$ glucanases from this medically important house dust mite. The genes encoding novel $\beta-1,3$ glucanases designated Glu1, Glu2 and Glu3 were identified in D. pteronyssinus airmid, each exhibited more than 59\% amino acid identity to one another. These enzymes are encoded by Glu genes present in a tri-gene cluster and protein homologs are found in other acari. The patchy phyletic distribution of Glu proteins means their evolutionary history remains elusive, however horizontal gene transfer cannot be completely excluded. Recombinant Glu1 and Glu2 exhibit hydrolytic activity toward laminarin, pachyman and barley glucan. Excreted $\beta-1,3$ glucanase activity was increased in response to $D$. pteronyssinus airmid feeding on baker's yeast. Active $\beta$ 1,3 glucanases are expressed and excreted in the faeces of $D$. pteronyssinus airmid indicating they are digestive enzymes capable of breaking down $\beta-1,3$ glucans of fungi present in house dust.
\end{abstract}

\section{Introduction}

House dust mites (HDMs) appear to have evolved from an avian parasite ancestor, which in turn may have evolved from a mycophagous free-living ancestor (Klimov and O'Connor, 2013; O'Connor, 1979). Close relatives of the most common house dust-dwelling acariforme mites; Dermatophagoides pteronyssinus, Dermatophagoides farinae and Euroglyphus maynei, exhibit facultative mycophagy (O'Connor, 1979). The stored product mite, Tyrophagous puterscentiae is frequently found to contaminate laboratory fungal cultures, feeding on hyphae and spores of dermatophytes, molds and yeasts (Duek et al., 2001). Recent studies have demonstrated $D$. pteronyssinus is better suited to nutritionally exploit fungi than $D$. farinae, and is capable of using yeasts and the filamentous fungi, Aspergillus and Penicillium spp. as food sources (Molva et al., 2019).
In order to feed on fungi, D. pteronyssinus must possess the enzymatic arsenal to degrade the microbe's cell wall and digest the cell contents (Erban and Hubert, 2012). A typical fungal cell wall is a multilayer structure composed of a chitin layer linked to a $\beta-1,3-$ and $\beta$ 1,6 -glucan layer, followed by an outermost layer of mannoproteins. $\beta$ glucans form $50-60 \%$ of the fungal cell wall with $\beta-1,3$ contributing $65-90 \%$ of the $\beta$-glucan content (Fesel and Zuccaro, 2016). Enzymes from the Glyco Hydrolase family 16 (GH16) exhibit hydrolytic activity against a variety of polysaccharides, including $\beta-1,3$ glucans commonly found in fungal cell walls (Alvarez et al., 2015). Enzymes capable of hydrolysing $\beta-1,3$ glucans exhibit endo- $\beta-1,3$ glucanase (EC 3.2.1.39), endo- $\beta-1,3-1,4$ glucanase (EC 3.2.1.6) or exo- $\beta-1,3$ glucanase activity (EC 3.2.1.58) (Song et al., 2010).

In previous work, we identified six putative GH16 proteins with predicted $\beta-1,3$ glucanase activity in $D$. pteronyssinus airmid, four were

\footnotetext{
* Corresponding author.

E-mail address: sean.doyle@mu.ie (S. Doyle).
} 


$\begin{array}{ll}\text { Abbreviations } \\ \text { HDM } & \text { House Dust Mite } \\ \text { HGT } & \text { Horizontal Gene Transfer } \\ \text { MES } & \text { 4-Morpholineethanesulfonic acid } \\ \text { MM } & \text { Minimal Media } \\ \text { HDMMM } & \text { HDM Maximal Media } \\ \text { PBS } & \text { Phosphate Buffered Saline } \\ \text { SM } & \text { Spent Culture Medium } \\ \text { MB } & \text { Mite Body }\end{array}$

validated as expressed (Waldron et al., 2019). Moreover, previous studies have demonstrated $\beta$ - glucosidase activity to be present in protein extracts from $D$. pteronyssinus (Martinez et al., 1999). This enzyme activity may be utilised by $D$. pteronyssinus for immune defence and/or digestive activities (Erban and Hubert, 2008; Pauchet et al., 2009).

GH16 proteins represent interesting targets for further study as active $\beta-1,3$ glucanases have been reported only in a handful of arthropods including Lepidoptera, Collembola and Diptera (Bragatto et al., 2010; Moraes et al., 2014). Moreover, they have been reported to be lost from Chelicerates (scorpions, mites, spiders and ticks) (Jiggins and Palmer, 2015). The unexpected discovery of an endo- $\beta-1,3$ glucanase in the Antarctic springtail, Cryptopygus antarcticus was explained by horizontal gene transfer (HGT) (Song et al., 2010). Thus, the presence of $\beta-1,3$ glucanases in the genome of $D$. pteronyssinus may also point to acquisition by HGT, as HGT has been seen previously in this species (Tang et al., 2017).

In the present study, we conducted an extensive bioinformatic and biochemical investigation of three recently discovered GH16 proteins with predicted $\beta-1,3$ glucanase activity to (i) examine the evolutionary history of predicted $\beta-1,3$ glucanases present in $D$. pteronyssinus (ii) conduct functional characterisation of predicted $\beta-1,3$ glucanases and (iii) examine if $D$. pteronyssinus utilise $\beta-1,3$ glucanases to digest the yeast, Saccharomyces cerevisiae.

\section{Materials and methods}

\subsection{Bioinformatic analysis}

The evolutionary history of the three Glu genes relative to closely related species was investigated by taking the three corresponding Glu protein sequences and using each as a query sequence in a BLASTp (Altschul et al., 1997) database search (e-value cutoff of $1 \mathrm{e}^{-10}$ ) against a local protein database containing eleven other Acari species. Six of these species belong to the Parasitiformes order while the remaining five belong to the Acariformes order (Table 1). Homologous sequences were retrieved and aligned using MUSCLE (Edgar, 2004) using the default settings. The resultant alignment was used to reconstruct a maximum likelihood tree using RAxML (Stamatakis, 2014) utilising the $\mathrm{LG}+\mathrm{G}+\mathrm{I}+\mathrm{F}$ model as selected by ProtTest (Darriba et al., 2011), branch supports were determined using 100 bootstrap replicates.

A broader evolutionary analysis was also undertaken by performing a BLASTp database search with an e-value cutoff of $1 \mathrm{e}^{-10}$ of the three Glu proteins against a dataset representative of fully sequenced prokaryotic and eukaryotic species. This dataset was composed of over 8 million protein sequences from 1,698 genomes sampled from all three domains of life which had been used in previous interdomain evolutionary analysis (McCarthy and Fitzpatrick, 2016). Homologous sequences were retrieved and aligned using MUSCLE using the default settings. The resultant alignment was used to reconstruct a maximum likelihood tree using FastTree2 (Price et al., 2010) utilising the LG model and local supports values were also determined.

\subsection{Protein extraction}

Culture and protein extraction from $D$. pteronyssinus airmid mite body (MB) and spent culture medium (SM) were conducted as described in Waldron et al. (2019). Briefly, SM was obtained by sieving ( $300 \mu \mathrm{m}$ mesh) whole cultures to remove mites and ultimately contained leftover diet, mite faeces and a small number of live mites (10.8 mites per mg). Proteins from SM were extracted by addition of glass beads and $1000 \mu \mathrm{l}$ lysis buffer, followed by bead-beating. Protein extracts were clarified by centrifugation to remove HDMs and insoluble debris. Following separation from whole cultures, HDMs were washed free of SM and then lyophilised. Lyophilised MBs were ground to a fine powder, protein was extracted and quantified.

HDM were cultured on a diet of dried porcine liver (MM) or a mixture of porcine liver and baker's yeast (HDMMM). HDMs were cultured on MM or HDMMM for three consecutive culture cycles (each of 28 days) before commencement of the study.

Table 1

Genome assemblies utilised for phylogenetic analysis.

\begin{tabular}{lll}
\hline Species & GenBank assembly accession & Genome Reference \\
\hline${ }^{a}$ Centruroides sculpturatus & GCA_000671375.2 & \\
${ }^{a}$ Parasteatoda tepidariorum & GCA_000365465.3 & Waldron et al. (2017) \\
${ }^{b}$ Dermatophagoides pteronyssinus airmid & GCA_001901225.2 & Liu et al. (2018) \\
${ }^{b}$ Dermatophagoides pteronyssinus & & Randall et al. (2018) \\
${ }^{b}$ Dermatophagoides pteronyssinus & Chan et al. (2015) \\
${ }^{b}$ Dermatophagoides farinae & GCA_000767015.1 & Rider et al. (2017) \\
${ }^{b}$ Euroglyphus maynei & GCA_002135145.1 & Rider et al. (2015) \\
${ }^{b}$ Sarcoptes scabiei & GCA_000828355.1 & Grbić et al. (2011) \\
${ }^{b}$ Tetranychus urticae & GC__000239435.1 & Burgess et al. (2018) \\
${ }^{c}$ Psoroptes ovis & GCA_002943765.1 & Schwager et al. (2017) \\
${ }^{c}$ Ixodes scapularis & GCA_002892825.2 & Gulia-Nuss et al. (2016) \\
${ }^{c}$ Galendromus occidentalis & GCA_000255335.1 & Barrero et al. (2017) \\
${ }^{c}$ Rhipicephalus microplus & GCA_002176555.1 & Dong et al. (2017) \\
${ }^{c}$ Tropilaelaps mercedesae & GCA_002081605.1 & Cornman et al. (2010) \\
${ }^{c}$ Varroa destructor & GCA_000181155.2 & \\
${ }^{c}$ Varroa jacobsoni & GCA_002532875.1 & \\
\hline
\end{tabular}

Genomes available for 11 species from the subclass Acari, six of these genomes belong to the Parasitiformes superorder while the remaining five belong to the Acariformes superorder. The evolutionary history of three Glu genes relative to closely related species was investigated by taking the three corresponding Glu protein sequences and using each as a query sequence in a BLASTp 1 (Altschul et al., 1997) database search (e-value cutoff of $1 \mathrm{e}^{-10}$ ) against a local protein database containing the eleven other Acari species listed. ${ }^{\text {a }}$ Arachnid outgroup.

${ }^{\mathrm{b}}$ Acariformes. ${ }^{\mathrm{c}}$ Parasitiforme. 


\subsection{Purification of $\beta-1,3$ glucanase from $D$. pteronyssinus airmid}

Gel filtration chromatography was carried out using an ÄKTA Purifier coupled with a Superdex 200 10/300 GL gel filtration column (GE Healthcare, Germany), equilibrated in Phosphate Buffered Saline (PBS). MB protein extracts were filtered $(0.22 \mu \mathrm{m})$, injected $(500 \mu \mathrm{l})$ and separated (flow rate $0.4 \mathrm{ml} / \mathrm{min}$ ) with absorbance monitored at 215, 254 and $280 \mathrm{~nm}$. Fractions were collected (between $\sim 8$ and $26 \mathrm{ml}$ ) and assayed for $\beta-1,3$-glucanase activity using the AZCLPachyman assay (described below). Fractions with detectable activity (16-22 $\mathrm{ml}$ post-injection) were pooled, buffer exchanged $(50 \mathrm{mM} \mathrm{4-}$ Morpholineethanesulfonic acid (MES), $\mathrm{pH}$ 5.5) and concentrated using centrifugal filters (Amicon; $3 \mathrm{kDa}$ MWCO). The resulting protein solutions were further fractionated by cation exchange chromatography, and the $\beta-1,3$ glucanases bound the column (HiTrap SP Xl) and were eluted with sodium chloride gradient $(60-90 \mathrm{mM} \mathrm{NaCl}$ in $50 \mathrm{mM}$ MES $\mathrm{pH}$ 5.5).

\subsection{Expression analysis by RT-PCR}

RNA was extracted from $D$. pteronyssinus airmid using methods for nucleic acid extraction in Waldron et al. (2017) using the Purelink RNA mini kit (Invitrogen) and cDNA synthesised (qScript; Quantabio). Expression of Glu1, Glu2 and Glu3 genes were assessed by RT-PCR of cDNA with reference to control gene Der p1, using primers listed in Table 2 .

\subsection{Recombinant protein expression}

D. pteronyssinus airmid Glu1, Glu2 and Glu3 genes (Genbank accession numbers: MN187001, MN187000 and MN187002, respectively) were commercially synthesised (IDT; USA) to allow for signal peptide removal, incorporation of terminal BglII and XhoI sites and codon optimisation for expression in Escherichia coli (S1 -S3 Data). Gene fragments were cloned into the pEX-N-GST Precision Shuttle vector (OriGene), recombinantly expressed in and purified from E. coli according to methods described by Dolan et al. (2014). Recombinant proteins were buffer exchanged ( $50 \mathrm{mM}$ sodium acetate, $\mathrm{pH} 6.0)$ and concentrated using centrifugal filters (Amicon; $3 \mathrm{kDa}$ MWCO). The identity of purified recombinant proteins was confirmed by performing in-gel proteolytic digestion followed by LC-MS analysis, as described by Shevchenko et al. (2006).

\subsection{Proteolytic digestion and nano-flow liquid chromatography electro-} spray ionization tandem mass spectrometry (LC-MS/MS) analysis of protein extracts

Protein extracts from $D$ pteronyssinus airmid were prepared and analysed by LC-MS/MS as described by Waldron et al. (2019). Protein identification and label free quantitative (LFQ) analysis was conducted using MaxQuant (Version 1.6.1.0; http://maxquant.org/), statistical analysis of MaxQuant output data was performed by Perseus (Version 1.6.2.2) as described in O'Keeffe et al. (2014) using a custom contaminants database containing yeast and porcine proteins (Waldron et al., 2019). Yeast-derived proteins are degraded by HDM during the feeding process and are effectively absent from SM prior to proteomic analysis.

\subsection{Proteomic evaluation of fungal proteins present in yeast-free spent medium protein extracts}

In silico analysis of fungal proteins present in yeast free cultures was conducted by searching LC-MS/MS spectra from Yeast free SM against a proteomic database containing 60,490 fungal proteins from species (S4 Data) previously identified to be present in $D$. pteronyssinus or $D$. farinae laboratory cultures (Molva et al., 2019). Proteins were considered present when: (i) a minimum of two peptides (1 unique) for each parent protein was observed and (ii) were identified in three of the four protein extract replicates.

\subsection{House dust protein extract analysis}

House dust protein extracts used in this study were provided by airmid healthgroup ltd (Dublin, Ireland). House dust protein extracts $(100 \mu \mathrm{l})$ were brought to a final concentration of $1 \mathrm{M}$ urea, then digested using methods described in Waldron et al. (2019). Resultant spectra were searched against proteomic databases (i) D. pteronyssinus airmid and (ii) Glucanase database containing 303 glucanases present in database (McCarthy and Fitzpatrick, 2016) using parameters described above. Statistical analysis of the correlation between $\beta-1,3$ glucanase activity $(\mathrm{mU} / \mathrm{ml})$, Der $\mathrm{p} 1(\mu \mathrm{g} / \mathrm{g})$ and LFQ intensity of Glu1, Glu2, Glu3 was performed using Graphpad (PRISM) statistical software, Spearman's correlation with $95 \%$ confidence interval. Resultant spectra were additionally searched against a proteomic database containing 303 glucanases present in database (McCarthy and Fitzpatrick, 2016) using parameters described above.

\subsection{Laminarin assay}

$\beta-1,3$ glucanase activity was measured using laminarin substrate $(\beta$ 1,3-1,6 glucan; L9634; Sigma). Protein extracts ( $50 \mu \mathrm{l} ; 0.2 \mathrm{mg} / \mathrm{ml})$, recombinant proteins $(50 \mu \mathrm{l} ; 0.125 \mathrm{mg} / \mathrm{ml}), \beta-1,3$ glucanase enzyme standard (67138; Sigma; $50 \mu \mathrm{l} ; 5 \mathrm{mU}$ ) and house dust protein extracts $(50 \mu \mathrm{l})$ were individually incubated with laminarin substrate as follows: $(200 \mu \mathrm{l} ; 0.25 \%(\mathrm{w} / \mathrm{v})$ laminarin; $50 \mathrm{mM}$ sodium acetate $\mathrm{pH} 6.0 ; 2.5 \mathrm{~h}$; $37^{\circ} \mathrm{C}$ ). Assays were terminated by heating samples $\left(90^{\circ} \mathrm{C} ; 5 \mathrm{~min}\right)$.

\subsection{Barley glucan assay}

$\beta-1,3-1,4$ glucanase activity was measured using low viscosity barley glucan (Megazyme, Ireland) using methods described for the laminarin assay.

\subsection{Glucose measurement assay}

Glucose measurement was performed according to Bethke and Busse (2008)with minor modifications. Sample/standard were diluted (1:10

Table 2

List of primers.

\begin{tabular}{|c|c|c|}
\hline Primer Name & $\begin{array}{l}\text { Annealing } \\
\text { Temperature }\left({ }^{\circ} \mathrm{C}\right)\end{array}$ & Sequence $\left(5^{\prime}-3^{\prime}\right)$ \\
\hline Derp1_F & 59 & TCGTCCATCATCGATCAAAA \\
\hline Derp1_R & & TCGATGTTGGCAGCAAAATA \\
\hline Glu1_Nat_F & 63 & ATGGCCAATTGGCAGATGGTC \\
\hline Glu1_Nat_R & & TTATCGCCATTGATAAACACGAACAT \\
\hline Glu3_Nat_F & 51 & ATGGCTTTTCTCTACTTCC \\
\hline Glu3_Nat_R & & TTATTTTTTTTGTTGATAAACAC \\
\hline Glu2_Nat_F & 50 & ATGCAAAATTTTCTTTTGTTT \\
\hline Glu2_Nat_R & & TTATTGTTGATAAACACGGAC \\
\hline Glu3_Nat_F & 51 & ATGGCTTTTCTCTACTTCC \\
\hline Glu3_Nat_R & & TTATTTTTTTTGTTGATAAACAC \\
\hline pEX-N-GST_F & 56 & AACGTATTGAAGCTATCCCAC \\
\hline pEX-N-GST_R & & TTCTACCATCGACACCACCA \\
\hline
\end{tabular}

Primers used for the amplification of Glu1, Glu2 and Glu3 (See text for Genbank Accession numbers) and Der p1 (Genbank Accession number: KJ542092.1) genes from gDNA and cDNA. pEX-N-GST primers designed to span the vector multiple cloning site. 
to $1: 80 ; 50 \mathrm{mM}$ sodium phosphate $\mathrm{pH} 7.4$ ), then added $(50 \mu \mathrm{l})$ to each microplate well. Enzyme-Ampliflu ${ }^{\circledast}$ Red mixture $(50 \mu \mathrm{l})$ was added and microplate was incubated in the dark (RT; $30 \mathrm{~min}$ ). Absorbance $(560 \mathrm{~nm})$ was measured (BioTek Instruments, Inc., USA). Enzyme mix sufficient for one plate was prepared by combining $50 \mu \mathrm{l}$ Ampliflu ${ }^{\circledR}$ Red reagent stock solution (Sigma 90101; $10 \mathrm{mM}$ in DMSO), $100 \mu \mathrm{l}$ horseradish peroxidase stock solution (Sigma P8375; $10 \mathrm{U} / \mathrm{ml}$ in $50 \mathrm{mM}$ sodium phosphate $\mathrm{pH}$ 7.4), and $100 \mu$ l glucose oxidase stock solution

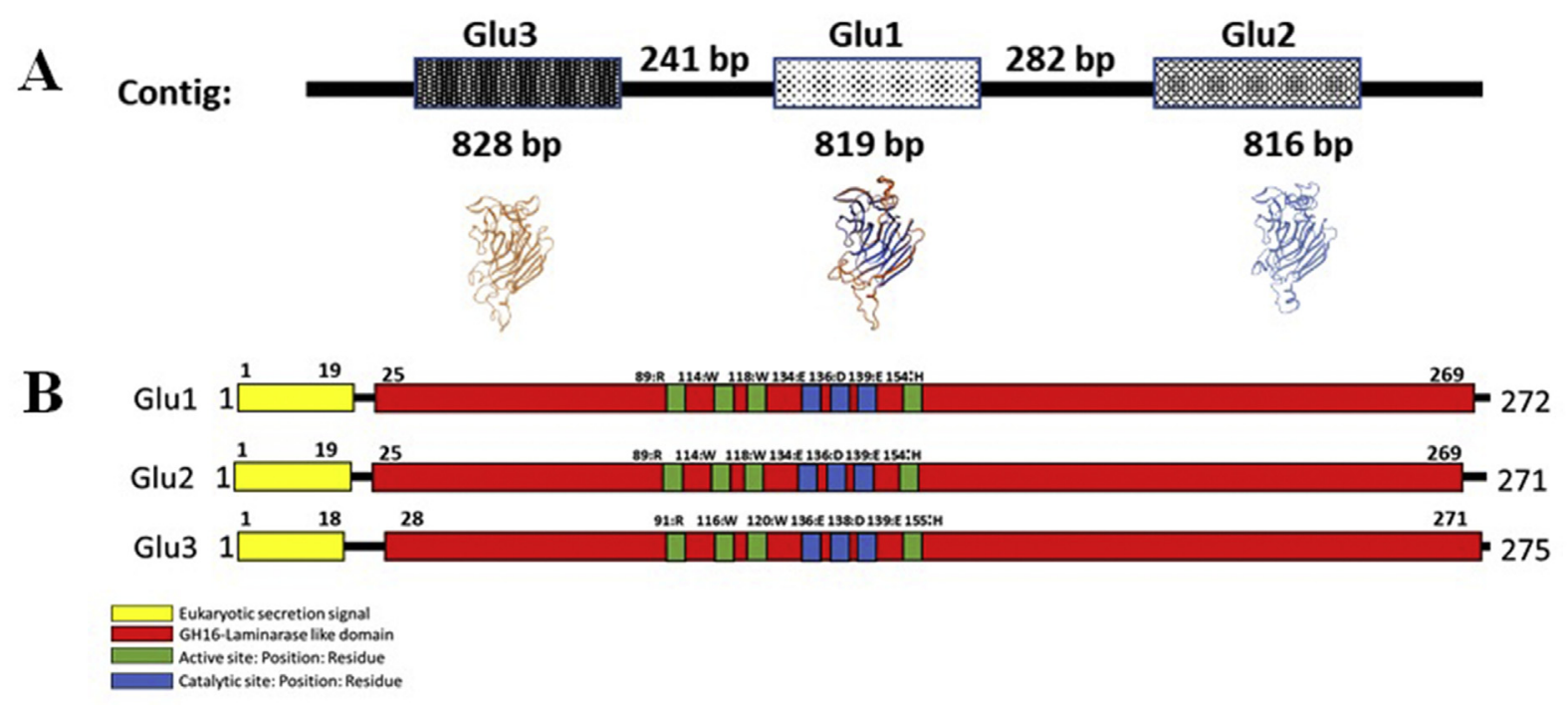

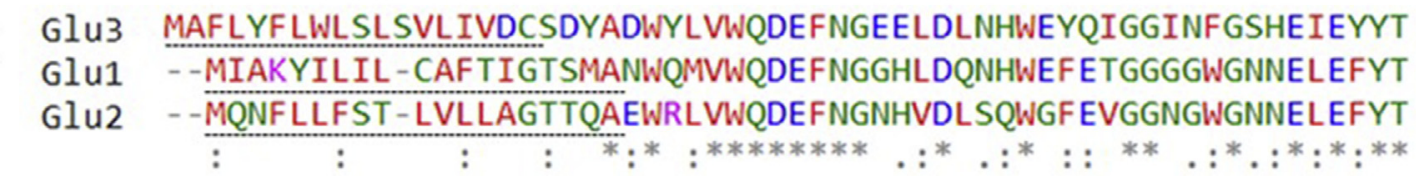

60

57

Glu3 -NRTKNVRIENGSLVIDAQIEKYDSYNFTSGRIHGKQSWTYGKFEARARLPSGHQLWPAI Glu1 ANRSQNVRVENGHLVIDVRVESYGGRDFTSGRIHSKQAWAYGKFEARARLPSGHHLWPAI

Glu2 YNRTENARIENGNLVIDVHVEDYRERQFTSARMHTKQAWKYGRFEIRARMPNGHNLWPAI

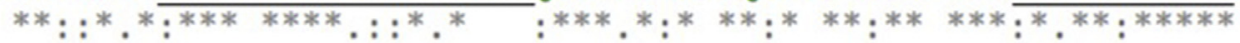

Glu3 WMMPHLSKYGSWAASGEIDIMENKGDHPAVIEATIHYGGKRPYNTHTGSGPRDFHCDLSK

Glu1 WMFPRDSKYGPWAASGEIDIMEYRGDVHDKIEGTIHYGGQWPNNIYTGSGPHHFNVDFSK

Glu2 WMMPLESIYGIWAASGEVDIAEFRGDILDKIEGTAHYGGTWPNNIYSGSGPRSFNVNFSQ

Glu3 DFHLYAIEWNAKEIRFYLDNNHYFTADIDRMMWSGKGPNPYTRKGQPFDQSFHWILNVAI

Glu1 DFHNFAVEWDTKEIRWYMDGNKYFSVNIDRNMWSGKGNNPYNKNGQPFDQPFRWILNVAV

Glu2 DFHTFALEWDHKQLRWYMDNQQYFSFDIDRMLWSGKGANPYTKNGQPFDQPFYLMLNVAV

Glu3 GGSYFGPGPYVTPEQAKHWPKSTMEIDYLRVYQQKK

Glu1 GGNFFGPGPYVTPDQARHWQKHTMEIDYVRVYQWR-

Glu2 GGNFFGPGPYVTPDQARQWPKHTFEIDYVRVYQQ- -

- Fully conserved residue

: Conservation between groups of strongly similar properties

- Conservation between groups of weakly similarproperties

- Gap

- Broken line indicates predicted secretion peptide

— Solid line indicates LC-MS/MS peptide coverage

Fig. 1. Bioinformatic Analysis of D. pteronyssinus Glucanase Trigene Cluster Containing Glu1, Glu2 \& Glu3. A. Illustration of Glu gene cluster depicting gene length, inter gene distance between Glu1, Glu2 and Glu3 and predicted 3D protein structure (swissmodel.expasy.org). B. Map of protein functional domains in Glu1, Glu2 and Glu3 predicted using InterproScan. C. Protein sequence alignment showing predicted secretion peptides (broken line) and LC-MS/MS sequence coverage (underlined). 
(Sigma G7141; $100 \mathrm{U} / \mathrm{ml}$ in $50 \mathrm{mM}$ sodium phosphate $\mathrm{pH} 7.4$ ) with $4.75 \mathrm{ml}$ of $50 \mathrm{mM}$ sodium phosphate $\mathrm{pH}$ 7.4. All stock solutions were frozen as aliquots at $-20^{\circ} \mathrm{C}$ prior to use. A glucose standard curve $(0-1.8 \mu \mathrm{g})$ enabled the glucose content of samples to be calculated.

\subsection{Glucanase quantification}

$\beta-1,3$ glucanase activity was quantified by performing laminarin assay followed by glucose measurement assay. Endogenous glucose in D. pteronyssinus airmid protein extracts was quantified using glucose measurement assay and subtracted from total glucose measured following laminarin assay. Relative specific $\beta-1,3$ glucanase activity was calculated with reference to $\beta-1,3$ glucanase enzyme standard. One unit of $\beta-1,3$ glucanase was defined as the amount of enzyme that liberated the equal amount of glucose from laminarin, to that of the $\beta-1,3$ glucanase standard under the conditions described above.

\subsection{AZCL-pachyman assay}

Endo- $\beta-1,3$ glucanase activity was measured using AZCL-Pachyman (Megazyme, Ireland). Briefly, recombinant proteins $(200 \mu \mathrm{l} ; 0.125 \mathrm{mg}$ / $\mathrm{ml})$ were incubated with the substrate $(800 \mu \mathrm{l} ; 0.25 \%(\mathrm{w} / \mathrm{v})$ AZCLPachyman; $50 \mathrm{mM}$ sodium acetate $\mathrm{pH} 6 ; 2.5 \mathrm{~h} ; 37^{\circ} \mathrm{C}$ ), centrifuged $(10,000 \mathrm{~g} ; 5 \mathrm{~min})$ and supernatant recovered. Samples were tested in triplicate; the mean absorbance was recorded $(600 \mathrm{~nm})$.

\subsection{AZCL-HE-cellulose assay}

Cellulase activity ( $\beta-1,4$ glucanase) was measured using AZCL-HECellulose (Megazyme, Ireland) using methods described for AZCLPachyman assay.

\subsection{Biochemical characterisation of recombinant glucanases}

Optimal pH and temperature of recombinant proteins was assessed by performing laminarin assays across $\mathrm{pH}$ range $(\mathrm{pH} 4,5,6,7,8,9)$ and temperatures $\left(4^{\circ} \mathrm{C}, 25^{\circ} \mathrm{C}, 30^{\circ} \mathrm{C}, 37^{\circ} \mathrm{C}, 50^{\circ} \mathrm{C}\right)$. Enzyme mixtures were neutralised (pH 7-8) and glucose concentration measured.

\section{Results}

\subsection{Bioinformatic analysis of D. pteronyssinus airmid glucanases}

Three GH16 genes with putative $\beta-1,3$ glucanase or $\beta-1,3-1,4$ glucanase activity were located in the $D$. pteronyssinus airmid genome assembly and designated Glu1 (DERPT_G3105; Genbank MN187001), Glu2 (DERPT_ G3104; Genbank MN187000) and Glu3 (DERPT_G3106; Genbank MN 187002) in order of their discovery. The genes had open reading frame lengths of $816-828 \mathrm{bp}$, were located within the same contig forming a tri-gene cluster, designated the Glu cluster, with intergenic distances of $241 \mathrm{bp}$ between Glu2 and Glu1, and 282 bp between Glu1 and Glu3 (Fig. 1A). The genes translated to Glu proteins that exhibited a high degree of amino acid (a.a) sequence similarity to one another ranging between 59\% and 69\% identity.

The Glu proteins of 272-275 a.a in length, each contained a signal sequence of 18-19 a.a. The Glu proteins are of a similar size (31.7-32.1 kDa) and contain a glycoside hydrolase family 16 (GH16) catalytic domain with catalytic residues (Fig. 1B). Proteomic analysis of $D$. pteronyssinus airmid excreted proteins present in SM resulted in the identification of all three $\beta-1,3$ glucanases with sequence coverage of 25.8-77.9\% (Fig. 1C).

A Blastp search of other Acari genomes (Table 1) identified three additional Glu homologs in D. pteronyssinus airmid (DERPT_G10990 (Genbank MN187003); DERPT_G6081 (Genbank MN187004) and DERPT_ G8787 (Genbank MN187005)) while five in total were found in D. farinae and four in E. maynei. Homologs were also located in Sarcoptes scabiei (two) and Psoroptes ovis (two) but absent from the Parasitiforme order. A maximum likelihood phylogeny was constructed which revealed that Glu1, Glu2 and Glu3 are grouped in a single clade with strong (86\%) bootstrap support (BP). Glu3 is grouped with orthologs from D. farinae and E. maynei (Fig. 2, 99\% BP). D. pteronyssinus Glu1 and Glu2 are grouped in a single clade with 87\% BP (Fig. 2). Based on our phylogeny, D. farinae and E. maynei have an ortholog of Glu1 but not of Glu2 (Fig. 2).

Blastp searched against a local proteome database located 299 homologs, primarily located in bacterial species but also select fungal species, two animals (Ciona intestinalis and Daphnia pulex), oomycetes such as Saprolegnia and Aphanomyces species as well as a number of diatoms including Ectocarpus and Aurococcus species. The resultant maximum likelihood phylogeny shows the majority of eukaryote homologs are located in a single highly supported clade (S1 Figure 78\% BP). Three of the Acariformes homologs (D. farinae, E. maynei and D.

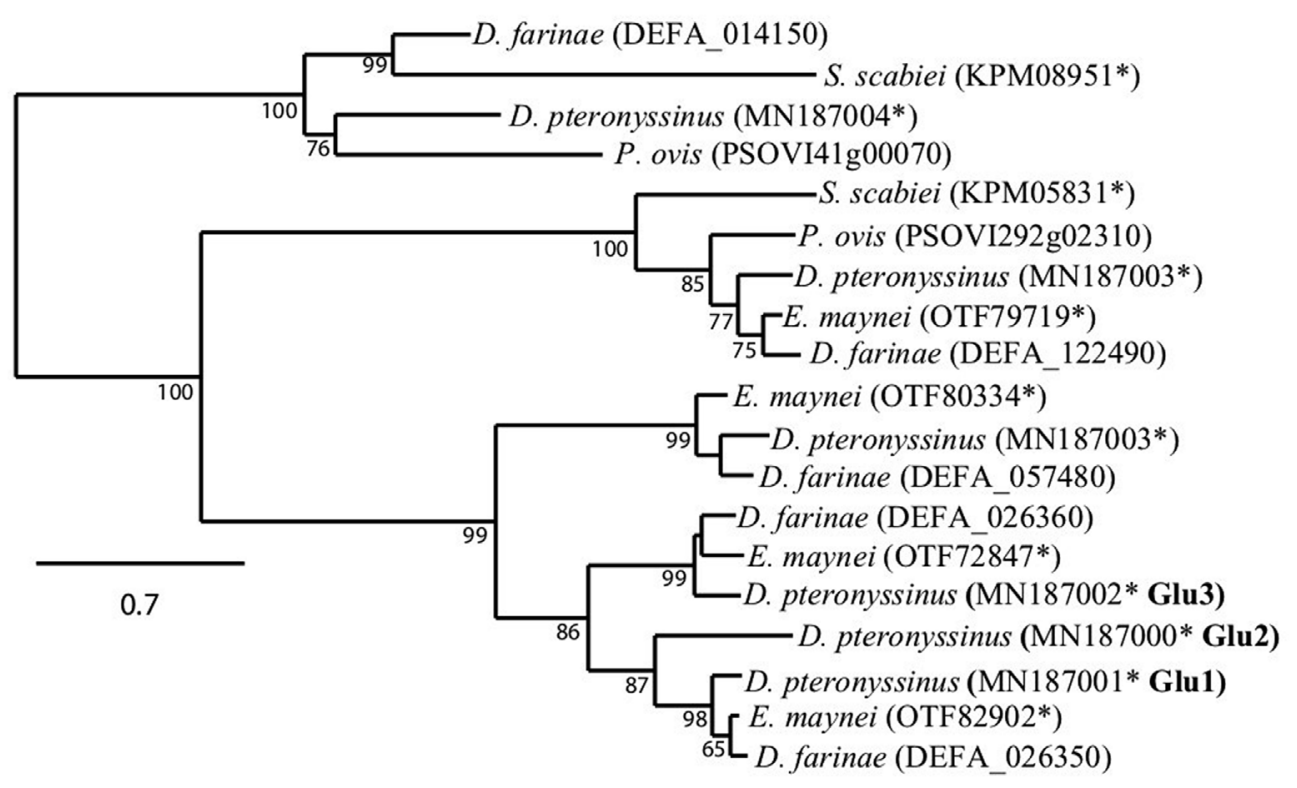

Fig. 2. Maximum Likelihood Phylogeny of Glu Homologs in Fully Sequenced Acari Proteomes. Bootstrap support values are shown at nodes. All homologs come from the Acariformes order, no homologs were located in members of the Parasitiforme order. NCBI Genbank accession numbers where applicable are shown in brackets and denoted with an Asterix. Accession numbers not denoted with an Asterix are not currently in Genbank and were given by the genome sequencers listed in Table 1. 
pteronyssinus airmid) share sister group relationships with bacterial homologs.

\subsection{LC-MS/MS identification of fungal proteins present in laboratory $D$. pteronyssinus cultures}

Metaproteomic analysis of yeast-free SM identified numerous proteins from fungal species previously identified in laboratory HDM cultures (Molva et al., 2019) to be present $(n=536)$. Protein identification was confirmed by detection of at least two peptides per protein, and percentage sequence coverage ranged from 1.3 to $83.9 \%$ across the entire protein dataset (S5 Data). A number of homologous proteins were assigned to more than one fungal species $(n=218)$.

\subsection{Enzyme purification and identification}

Identification of $\beta-1,3$ glucanase active native protein (Glu1) was facilitated by a two-step purification workflow (Fig. 3A-D), the $\beta-1,3$ glucanase active fraction was visualized by SDS-PAGE (Fig. 3E) and bands excised for identification by LC-MS/MS (Fig. 3F). High confidence identification of putative $\beta-1,3$ (4) glucanase (DERPT_G3105) of approximately $25 \mathrm{kDa}$ in size was achieved with $70.6 \%$ coverage and identification of 19 peptides. Purification resulted in the recovery of $20 \mu \mathrm{g}$ of glucanase enriched extract with specific activity $670 \mathrm{mU} / \mathrm{mg}$ from $1.4 \mathrm{mg}$ of starting material with $106 \mathrm{mU} / \mathrm{mg}$ specific activity, summarised in Table 3.

\subsection{Cloning and expression}

Total RNA was extracted from $D$. pteronyssinus airmid and converted to cDNA. RT-PCR analysis was performed using intron containing control gene, Der p1. Absence of genomic DNA was confirmed by the smaller amplicon size of the Der $p 1$ cDNA amplicon relative to the corresponding genomic amplicon (Fig. 4A). Glu1, Glu2 and Glu3 amplicons from cDNA and genomic DNA were of identical size, confirming absence of introns. Amplicons derived from cDNA confirmed expression of all three genes in the Glu gene cluster (Fig. 4A). Commercially synthesised Glu1, Glu2 and Glu3 in expression vector pEX-N-GST (Fig. 4B) were expressed in E. coli with an N-terminal GST tag. Recombinant proteins were purified by affinity chromatography as determined by SDS-PAGE and Western blot analysis (Fig. 4C and D). SDS-PAGE gel bands corresponding to recombinant proteins were excised (Fig. 4C), proteins were digested, and peptides were identified by LC-MS/MS (Fig. 4E) confirming expression and successful purification of the three recombinant proteins.

\subsection{Substrate specificity and relative specific activity of Glu1 and Glu2}

Four substrates were used to test the ability of GST-rGlu1, GSTrGlu2 and GST-rGlu3 to hydrolyse $\beta-1,3-1,6$ glucans, $\beta-1,3$ glucans, $\beta$ $1,3-1,4$ glucans and $\beta-1,4$ glucans. Activity for GST-rGlu1 and GSTrGlu2 was highest on laminarin ( $\beta-1,3-1,6$ glucan) resulting in $37 \%$ and $8 \%$ of substrate hydrolysis, respectively, compared to only $7 \%$ and $2 \%$ on barley glucan ( $\beta-1,3-1,4$ glucan) (Fig. 5A). GST-rGlu2 exhibited approximately $20 \%$ of the hydrolytic activity of GST-rGlu1 on laminarin and barley glucan, and 33\% on AZCL-Pachyman ( $\beta-1,3$ glucans) (Fig. 5B). GST-rGlu1 showed highest relative specific activity on laminarin substrate with $743.5 \mathrm{mU} / \mathrm{mg}$ and GST-rGlu2 with $158.3 \mathrm{mU} / \mathrm{mg}$ (Fig. 5C). GST-rGlu1 and GST-rGlu2 were unable to hydrolyse AZCLHE-cellulose ( $\beta-1,4$ glucan) and GST-rGlu3 was found to be inactive on all substrates (data not shown).

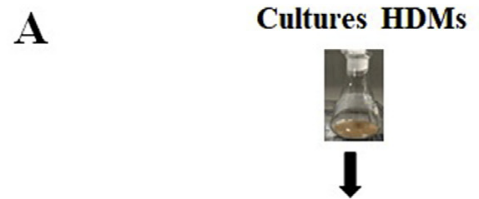

B Saturated saline flotation,
lyophilisation, lysis and
protein extraction.

C

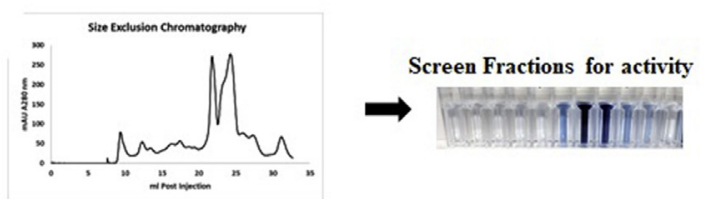

D

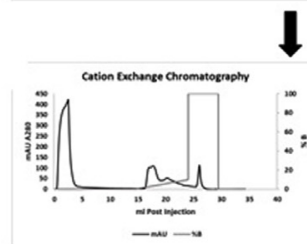

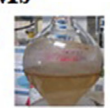

I
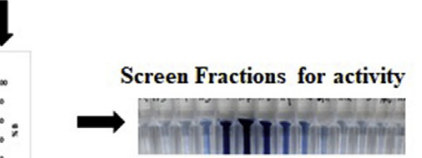

$\mathbf{E}$

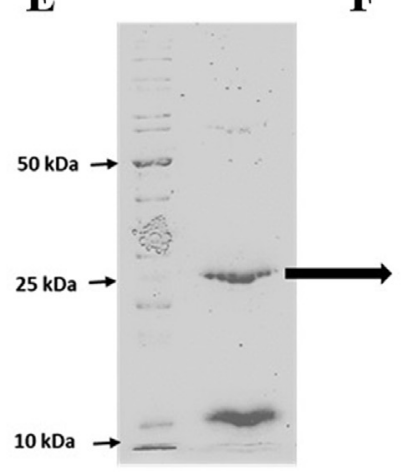

G
DERPT_G3105 Glu 1 Protein Sequence Coverage

MIAKYILILCAFTIGTSMAN WQMVWQDEFN GGHLDQNHWE FETGGGGWGN NELEFYTANR SQNVRVENGH LVIDVRVESY GGRDFTSGRI HSKQAWAYGK FEARARLPSG HHLWPAIWMF PRDSKYGPWA ASGEIDIMEY RGDVHDKIEG TIHYGGQWPN NIYTGSGPHHF NVDFSKDFHNF AVEWDTKEIRW YMDGNKYFSV NIDRNMWSGK GNNPYNKNGQ PFDQPFRWIL NVAVGGNFFG PGPYVTPDQA RHWQK $\underline{\text { HTMEI }}$ DYVRVYQWR

\begin{tabular}{lcccc}
\hline Protein & Score & Coverage & \# peptides & MW kDa \\
\hline Glul & 173.18 & 70.59 & 19 & 31.7 \\
\hline
\end{tabular}

Fig. 3. Workflow Depicting Purification and Subsequent Identification of Novel Glucanase, Glu1 (DERPT_G3105) from D. pteronyssinus airmid Protein Extracts. Flow diagram depicting proteomic strategy for the identification of the glucanases from $D$. pteronyssinus airmid. A. D. pteronyssinus airmid were cultured for 28 days, then B. Separated from culture medium using the saturated saline flotation method and proteins from whole body homogenate were extracted. C. Gel filtration chromatography of $D$. pteronyssinus airmid whole body homogenate. Protein extract $(2.75 \mathrm{mg} ; 500 \mu \mathrm{l}$ injection) separated by size exclusion chromatography (Superdex 200 10/300 GL; $0.4 \mathrm{ml} / \mathrm{min}$ flow rate). Fractions ( $2 \mathrm{ml}$ ) were collected between $8 \mathrm{ml}$ and $26 \mathrm{ml}$ post-injection and assayed for glucanase activity. Positive fractions (16-22 ml post-injection) were pooled and further separated by D. Cation exchange chromatography. Glucanases bound the column (HiTrap SP Xl) and were eluted in 60-90 mM NaCl. E. SDS-PAGE analysis of glucanase active semi-purified native protein elution F. LC-MS/MS of SDS-PAGE band at approximately $25 \mathrm{kDa}$ identified a putative $\beta-1,3-1,4$ glucanase designated Glu1, predicted eukaryotic secretion signal highlighted in bold. G. High confidence identification of $D$. pteronyssinus Glu1 protein by LC-MS/MS with $70.6 \%$ sequence coverage. 
Table 3

Purification of $\beta-1-3$ glucanase Active Fraction from $D$. pteronyssinus airmid Protein Extracts.

\begin{tabular}{|c|c|c|c|c|c|c|}
\hline Purification Step & Volume (ml) & Total Protein (mg) & Total Activity (mU) & Specific Activity (mU/mg)* & Yield (\%) & Purification Factor \\
\hline Crude enzyme & 0.5 & 1.4 & 148 & 106.07 & 100 & 1 \\
\hline Gel Filtration & 0.4 & 0.48 & 221 & 460.01 & 146 & 4.3 \\
\hline Cation Exchange & 0.1 & 0.02 & 13.4 & 670.45 & 8.8 & 6.3 \\
\hline
\end{tabular}

Crude enzyme (106 mU/mg) was separated by gel filtration chromatography, $\beta-1-3$ glucanase active fractions (16-22 ml post-injection) were pooled, concentrated and buffer exchanged into $50 \mathrm{mM}$ MES pH 5.5 for cation exchange separation. Glucanases bound the column (HiTrap SP Xl) and eluted between 60 and $90 \mathrm{mM}$ sodium chloride. The resultant $\beta-1-3$ glucanase active fraction contained $20 \mu \mathrm{g}$ protein with relative specific activity of $670 \mathrm{mU} / \mathrm{mg}$. Typical values given. *One unit of $\beta-1,3$ glucanase was defined as the amount of enzyme that liberated the equal amount of glucose from laminarin, to that of the $\beta-1,3$ glucanase standard.
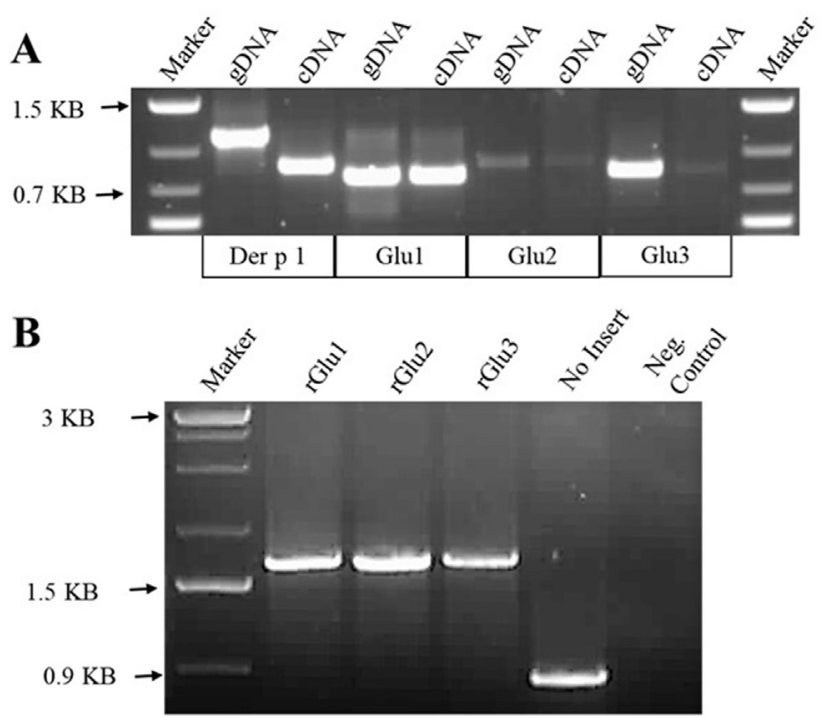

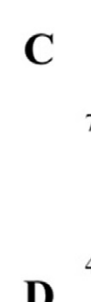

D
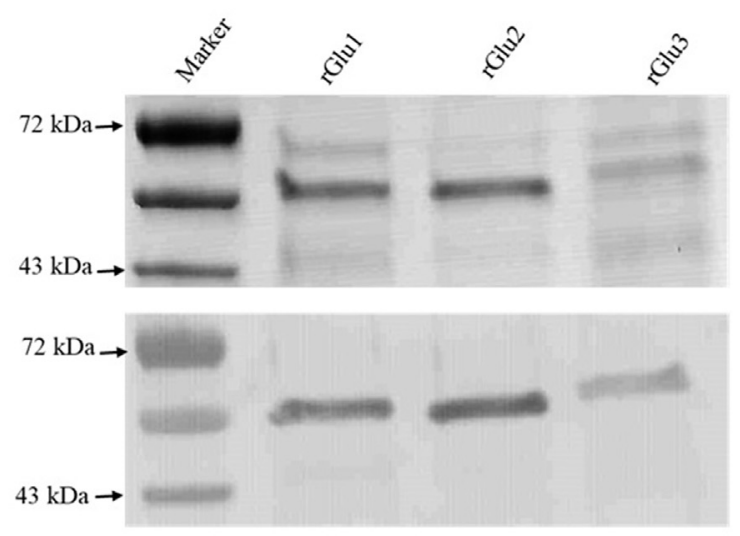

$\mathbf{E}$

\begin{tabular}{lrrrrr}
\hline Protein & \multicolumn{1}{c}{ Score } & \multicolumn{2}{c}{ Coverage \# Peptides } & \# PSMs & \multicolumn{1}{c}{ MW } \\
{$[\mathrm{kDa}]$}
\end{tabular}

Fig. 4. Cloning and Recombinant Protein Expression of D. pteronyssinus Glucanase Trigene Cluster Containing Glu1, Glu2 \& Glu3. A. RT-PCR of Glu1, Glu2 \& Glu3 from genomic DNA (gDNA) and cDNA confirming gene expression and absence of introns. Der $p 1$ gene containing three introns revealed gDNA amplicon of $\sim 1135$ bp and cDNA amplicon of $\sim 867$ bp. B. PCR confirmation of insertion of $E$. coli codon-optimised rGlu1, rGlu2 and rGlu3 gene sequences into pEX-N-GST expression vector. Amplicons containing insert were seen at $\sim 1700 \mathrm{bp}$ and amplicons from empty plasmid were seen at $\sim 900 \mathrm{bp}$. C. SDS-PAGE of affinity purified GST-rGlu1, GST-rGlu2 and GST-rGlu3 and D. Western blot of same using an anti-GST antibody. E. LC-MS/MS of GST-rGlu1, GST-rGlu2 and GST-rGlu3 excised from SDS-PAGE gel (Fig. 4C) confirming protein expression and successful purification. * PSMs; Peptide Spectrum Matches.

A

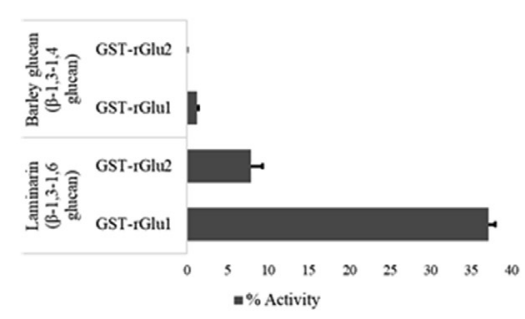

D

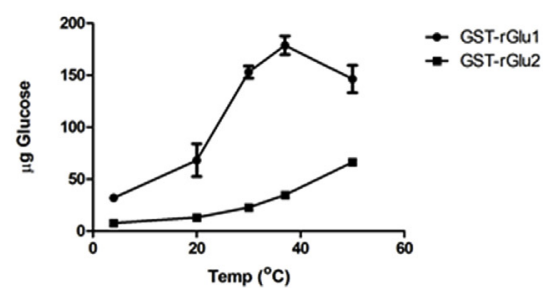

B

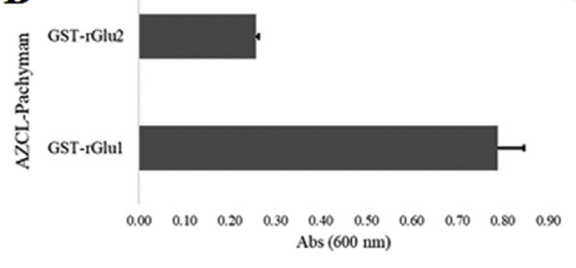

$\mathbf{E}$

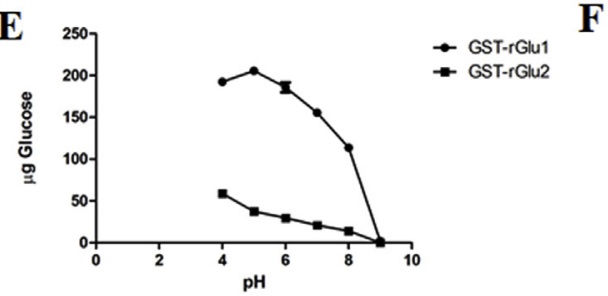

C

Relative Specific Glucanase Activity

\begin{tabular}{ll}
\hline Enzyme & $\mathrm{mU} / \mathrm{mg}^{*}$ \\
\hline GST-rGlu1 & $743.5 \pm 15.7$ \\
GST-rGlu2 & $158.3 \pm 28.3$ \\
GST-rGlu3 & $0 \pm 0$
\end{tabular}

*Mean relative specific activity measured on laminarin substrate and calculated relative to enzyme standard $\pm \mathrm{SD}$.

F

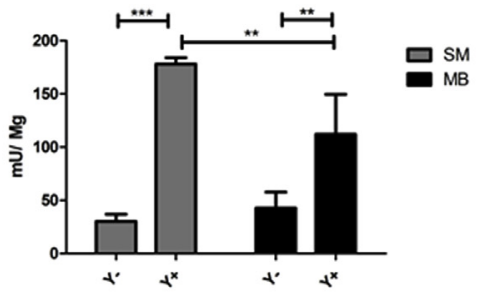

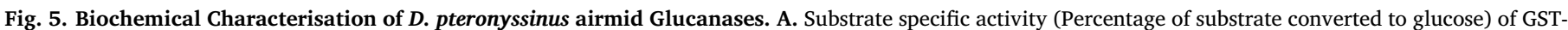

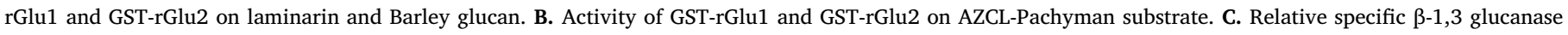

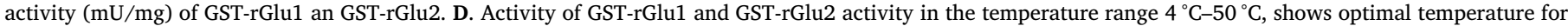

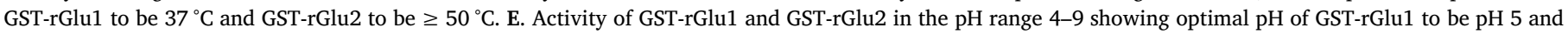

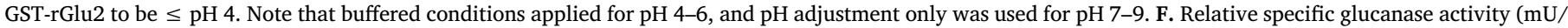

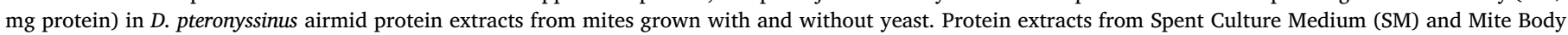

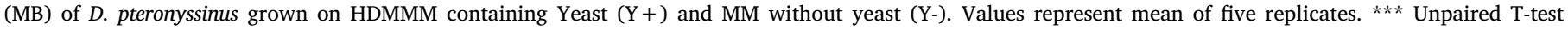
$P \leq 0.001$. ** Unpaired T-test $P \leq 0.01$. A-C, E-F: Values: mean values from triplicate sampling. Error bars: SD. 


\subsection{Effects of temperature and $p H$ on enzyme activity}

An evaluation of temperature on GST-rGlu1 and GST-rGlu2 hydrolytic activity against laminarin showed an increase in activity as temperatures increased peaking at $37{ }^{\circ} \mathrm{C}$ for GST-rGlu1 and $50{ }^{\circ} \mathrm{C}$ for GSTrGlu2 (Fig. 5D). The effect of $\mathrm{pH}$ on hydrolysis of laminarin was also determined, both GST-rGlu1 and GST-rGlu2 showed activity in the $\mathrm{pH}$ range 4.0-8.0. Maximum hydrolytic activity was observed at $\mathrm{pH} 5.0$ for GST-rGlu1 and pH 4.0 for GST-rGlu2 (Fig. 5E).

\subsection{Internal and excreted HDM glucanase activity and abundance increased on yeast-based diet}

Protein extracts from MB $(n=5)$ and SM $(n=5)$ of $D$. pteronyssinus airmid cultured on growth medium, with (HMDMM) and without yeast (MM), were assayed for $\beta-1,3$ glucanase activity. Extracts were incubated with laminarin substrate, released glucose was quantified by subtracting endogenous glucose present in protein extracts (approx. $6-28 \%$ of total glucose). Specific $\beta-1,3$ glucanase activity in MB of $D$. pteronyssinus airmid fed yeast was higher than in HDMs cultured without yeast $(P=0.0088)$, this difference was also consistent in the SM $(P<0.0001)$. There was no significant difference in $\beta-1,3$ glucanase activity found between MB and SM of HDMs cultured without yeast $(P=0.167)$ however, a significant difference was seen when HDMs were fed yeast $(P=0.0083$ ) (Fig. 5F). Comparative proteomic analysis of SM $(n=4)$ from $D$. pteronyssinus airmid grown with and without yeast revealed all three $\beta-1,3$ glucanases increased in abundance (20-39\%) in the SM of HDMs fed yeast (Table 4, S6 Data). A parallel proteomic analysis of the MB $(n=4)$ showed mean increases of all three $\beta-1,3$ glucanases when HDMs were fed yeast (Tables 4 and S7 Data).

\subsection{Glucanase activity in house dust correlates with Glu1/2 presence}

Protein extracts from HD positive for Der p1 $(0.2-16.94 \mu \mathrm{g}$ Der $\mathrm{p} 1$ per gram house dust) contained $\beta-1,3$ glucanase activity (Range; 2.5-370 mU/ml), activity levels correlated with Der p1 concentration (Fig. 6A). Subsequent proteomic analysis identified Glu1 or Glu2 to be present in many of the HD extracts $(n=16)$, nine extracts were found to contain both enzymes. LFQ intensity of both Glu1 and Glu2 correlated significantly (Spearman's correlation) with relative specific $\beta-1,3$ glucanase activity (Fig. 6B and C). Proteomic interrogation of glucanases present in database (McCarthy and Fitzpatrick, 2016) confimed the presence of Glu1 and Glu2 and failed to identify any glucanases from other species (S8. Data).

\section{Discussion}

HDM are trophic generalists feeding on pollen, bacteria, plant fibres, fungal mycelia and spores associated with their human proximity habitats (Colloff, 2009; van Bronswijk, 1973). $\beta-1,3$ glucan content of house dust ranges between 15 and 79,000 $\mu$ g per gram and may be an important part of the HDM diet in the home (Brooks et al., 2013; Maheswaran et al., 2014). $\beta$-glycosidase activity has been reported previously in enzymatic studies of $D$. pteronyssinus however no specific proteins were linked to the activity seen (Martinez et al., 1999). Studying the expression, localisation and biochemical activity of HDM enzymes can allow for insight into their physiological function (Erban and Hubert, 2012).

To date, biochemical characterisation of D. pteronyssinus proteins have primarily focused on allergenic proteins (Bordas-Le Floch et al., 2017). In the present study, we conducted an extensive bioinformatic and biochemical investigation of three recently discovered GH16 proteins to gain insight into their role in $D$. pteronyssinus digestion.

Glu genes coding for these Glu proteins lacked introns and were found adjacent to one another, forming a tri-gene cluster designated, the Glu cluster. A further three homologs for Glu proteins were located in the genome of $D$. pteronyssinus airmid outside of the Glu cluster. Molecular phylogeny of these Glu proteins confirms their close relatedness with several Acariformes $\beta-1,3$ glucanases, with homologs found in other HDM species (D. farinae \& E. maynei) and closely related parasitic mites ( $P$. ovis \& $S$. scabei). Glucanase genes were expanded in HDMs, which contained between four and six homologs, compared to the parasitic Acariformes which contained only two copies. Interestingly, none of the six species from the Parasitiforme order contained homologs, suggesting glucanase activity is a recent adaption in Acariformes. Interestingly, our phylogeny demonstrates that $D$. pteronyssinus has an additional Glu (Glu2) homolog, not seen in the other two HDMs (Fig. 2). Based on its genomic location and high sequence identity, it appears to be a tandem duplication of Glu1. We are confident this is not an assembly/annotation error as this ortholog is present in a separate $D$. pteronyssinus assembly (Randall et al., 2018). Moreover, the expression of all three Glu genes was been confirmed by RT-PCR and their translation into protein confirmed by proteomic analysis, both in the course of this study and in previous work (Waldron et al., 2019). Recent studies have demonstrated $D$. pteronyssinus is better suited to nutritionally exploit fungi than $D$. farinae, and is capable of using yeasts and filamentous fungi as a food source (Molva et al., 2019). The presence of an additional Glu protein in $D$. pteronyssinus may allow it to exploit different nutrients than $D$. farinae, namely fungi, thus explaining why the presence of one species does not influence the numbers found of the other (Zock et al., 2006). Moreover, D. farinae exhibit a higher rate of population growth on bacteria-enriched diets than $D$. pteronyssinus (Erban and Hubert, 2008). The two mites may be utilising different components of house dust for food, with $D$. farinae better adapted to the exploitation of bacteria and $D$. pteronyssinus adapted for the exploitation of fungi.

To further investigate the evolutionary history of the three Glu genes, we searched their protein sequences against taxonomically diverse proteomes including prokaryotes, plants, fungi, heterokonts and

Table 4

Label-free quantitative (LFQ) proteomic LC-MS/MS of Proteins Excreted by D. pteronyssinus airmid cultured With and Without Yeast.

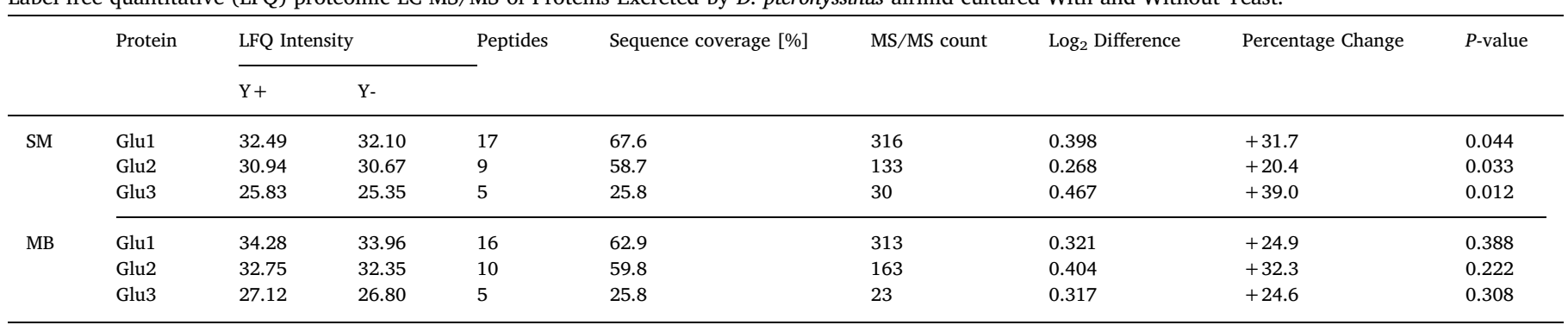

Proteins from SM and MB from D. pteronyssinus airmid fed with yeast $(\mathrm{Y}+$ ) or without yeast (Y-) were extracted, normalised and analysed by LC-MS/MS. Glu1, Glu2 and Glu3 were present in higher abundance in both in SM and MB of D. pteronyssinus airmid fed with yeast. LFQ intensity: Log (2), mean of four replicates. $P$-value: Students T-test. Y+: Growth media containing bakers' yeast. Y-: Growth media without bakers' yeast. SM: Spent Culture Medium. MB: Mite Body. 

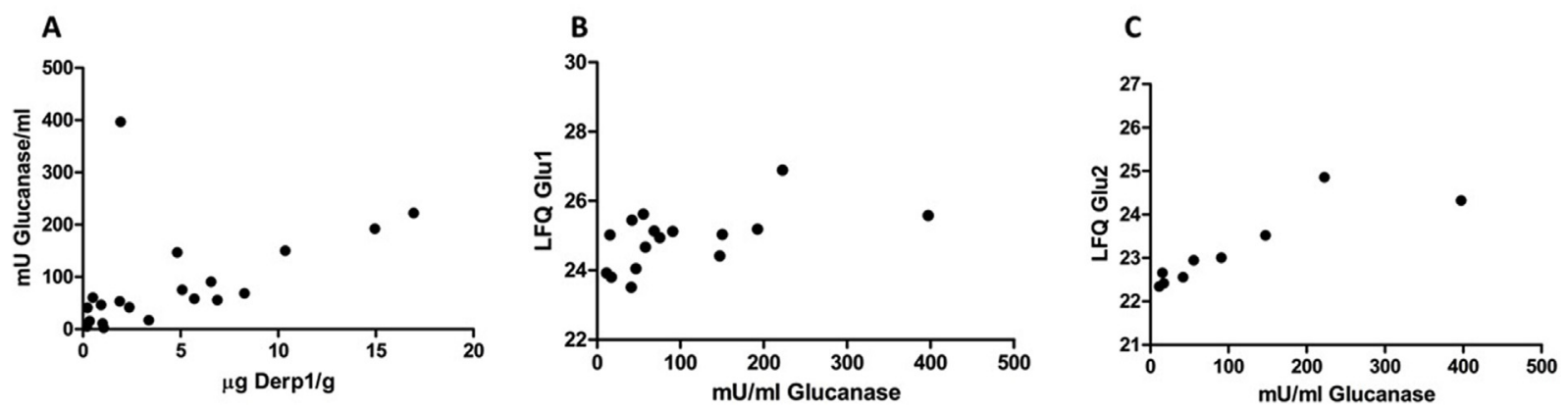

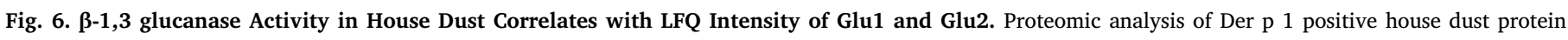

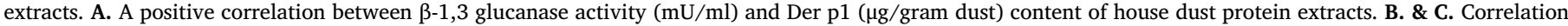

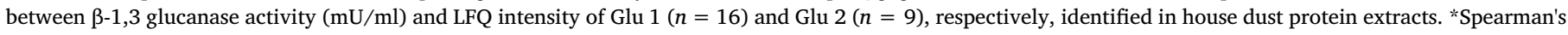
Correlation $p \leq 0.05 * *$ Spearman's Correlation $p \leq 0.005 * * *$ Spearman's Correlation $p \leq 0.0001$.

animals (McCarthy and Fitzpatrick, 2016) and reconstructed a phylogenetic tree. The majority of eukaryote homologs including Glu1, 2 \& 3 are located in a single highly-supported clade (S1. Figure, 78\% BP). Interestingly, three separate Glu Acariformes homologs ( $D$. farinae, $E$. maynei and $D$. pteronyssinus airmid) share a sister group relationship with bacterial homologs (S1. Figure). Some of the inconsistencies in the phylogenetic placement of eukaryote and prokaryote homologs may be due to HGT (Fitzpatrick, 2012) or other phylogenetic artefacts, such as long branch attraction (Felsenstein, 1978). To confidently infer potential HGT, a more comprehensive phylogenetic analysis is required. Such an analysis is beyond the scope of this work. However, we can confidently say that the distribution of Glu homologs amongst the eukaryotes in our proteome database is patchy at best. We are cognisant our inferences may be influenced by taxon sampling issue as our local proteome database consists of a large proportion of bacterial sequences (56\%). To further investigate this we searched all three Glu proteins against the non-redundant database of GenBank (Sayers et al., 2019). As with our local proteome database search results the vast majority $(\sim 80 \%)$ of homologs located in GenBank are bacterial in origin. A number of additional eukaryote homologs from species not in our local database were located including homologs in the snowberry fruit fly (Rhagoletis zephyria), springtails (Folsomia candida, Cryptopygus antarcticus and Orchesella cincta) and, of special noteworthiness, the mycophagous amoeba Planoprotostelium fungivorum. Therefore, additional database search of the Glu proteins against GenBank confirms that the distribution of these proteins in eukaryotes is patchy.

Fractionation of $D$. pteronyssinus airmid MB protein lysates via a combination of gel filtration and cation exchange chromatography resulted in a semi-pure protein preparation which retained $\beta-1,3$ glucanase activity. SDS-PAGE of this fraction and subsequent high-sensitivity mass spectrometric analysis of a band corresponding to $25 \mathrm{kDa}$ revealed the presence of a putative $\beta-1,3-1,4$ glucanase (DERPT_G3105; Glu1). Thus, confirming the source of $\beta-1,3$ glucanase activity seen in $D$. pteronyssinus airmid protein extracts was from the mites themselves and not microbes present in the cultures.

The low yield of purified native $\beta-1,3$ glucanase necessitated the generation of recombinant proteins to allow for full biochemical characterisation. Recombinant proteins were purified by affinity chromatography, however solubility was poor with soluble enzyme accounting for $<0.5 \%$ of the total protein of crude cell-free extract. Enzyme activity analysis of purified recombinant GST-rGlu1 and GST-rGlu2 confirmed that they are $\beta-1-3$ glucanases, with highest hydrolytic activity seen against laminarin substrate and moderate activity on AZCLPachyman and barley glucan. None of the three recombinant proteins exhibited $\beta-1-4$ glucanase activity against AZCL-HE-Cellulose. This biochemical analysis has confirmed Glu1 and Glu2 to be laminarinases (EC 3.2.1.6) capable of hydrolysing $\beta-1,3$-glucans and mixed $\beta-1,3-1,4$ / $\beta-1,3-1,6$ glucans. The anterior midgut of Dermatophagoides spp, the site of nutrient utilisation, is an acidic environment, with $\mathrm{pH}$ ranging from 4 to 5 (Colloff, 2009; Erban and Hubert, 2010). HDM enzymes with maxima outside of this $\mathrm{pH}$ range are unlikely to have digestive function in the gut lumen (Erban and Hubert, 2010). Our study of Glu proteins observed peak enzyme activity for GST-rGlu1 at a pH 5 and temperature of $37^{\circ} \mathrm{C}$. GST-rGlu2 showed optimal activity at lower $\mathrm{pH}(\mathrm{pH} 4)$ and higher temperature $\left(50^{\circ} \mathrm{C}\right)$. The $\mathrm{pH}$ optima for both GST-rGlu1 and GST-rGlu2 was within the physiological gut $\mathrm{pH}$ indicating that these Glu proteins are enzymatically active in the gut lumen (Erban and Hubert, 2010).

Recombinantly expressed GST-rGlu3 lacked hydrolytic activity against all substrates tested. This may be a result of $E$. coli as a poor choice of expression system resulting in the production of an inactive enzyme. The increased excretion of Glu3 in the SM of $D$. pteronyssinus airmid fed a diet containing yeast is a strong indicator that it is a digestive enzyme, expression of rGlu3 in an alternative expression system may yield an active protein in future studies.

In laboratory HDM cultures, fungi and bacteria are constitutively present, and their growth is kept to a minimum by limiting humidity and regular sub-culturing of HDMs (Colloff, 2009; Molva et al., 2018). Laminarinase activity was observed in the MB and SM of D. pteronyssinus airmid fed MM lacking yeast, indicating a basal level of expression and excretion in response to microbes naturally present in their environment (Molva et al., 2018). Moreover, despite having a pH optimum in the physiological gut range of $\mathrm{pH} 4-5$, Glu proteins are active in the SM unlike other digestive enzymes such as Der p1 which requires activation by reducing agents (Kauffman et al., 2006; Deb et al., 2007). This may indicate a dual role for these Glu proteins, in both immune defence and digestion. Metaproteomic analysis of fungal proteins present in the yeast-free SM identified two 1,3-beta-glucanosyltransferases, one from Aspergillus ruber and the other from Aspergillus versicolor (S5 Data). The expression of these mycelial modifying enzymes may be in response to the presence of glucan-degrading enzymes produced by D. pteronyssinus (Gastebois et al., 2010).

During basal expression, there was no significant difference in laminarinase activity between the MB and SM. However, when fed heatkilled yeast, laminarinase activity was increased 2.6-fold internally in the MB and 5.9-fold externally in SM. Comparative proteomic analysis supported these assay results, identifying Glu1, Glu2 and Glu3 to be increased in abundance (20-39\%) in the SM from HDMs fed on yeast (Tables 4 and S6 Data). Other studies have demonstrated that D. pteronyssinus is capable of fully digesting S. cerevisiae (Molva et al., 2018), and here we have demonstrated that they increase the production of three $\beta-1-3$ glucanase in response to feeding on this yeast. Moreover, a number of other enzymes were identified as uniquely present in the SM of yeast fed mites, including three alpha-mannosidase (DERPT_G10145, DERPT_G9692 \& DERPT_G222, S9 Data). In the MB, DERPT_G9692 and DERPT_G222 were not identified, however a fourth lysosomal alphaglucosidase (DERPT_G9698.t1) was identified in their absence (S7 Data). Mannoproteins form the outermost layer of the yeast cell wall 
and $40 \%$ of the carbohydrate content (Aguilar-Uscanga and Francois, 2003; Fesel and Zuccaro, 2016). Laminarases are frequently used to remove mannoproteins from $S$. cerevisiae and disrupt the cell wall (Van Rinsum et al., 1991). It is possible that Glu1, Glu2 and Glu3 remove this mannoprotein layer which is then further hydrolysed by these mannosidases.

Protein extracts from HD contained notable laminarinase activity, correlating significantly $(P=0.0001)$ with $D$. pteronyssinus biomarker Der p1. Moreover, proteomic analysis facilitated the identification of Glu1 and Glu2, and correlation between laminarase activity in HD and LFQ intensity of Glu1 and Glu2 (Fig. 6B and C). In house dust from floors and mattresses the fungal species frequently identified by highthroughput DNA sequencing, to be of high abundance are; Aspergillus spp, Cladosporium spp., Penicillium spp. and Alternaria spp. (Kaarakainen et al., 2009; Rintala et al., 2012; Sousa et al., 2014). D. pteronyssinus has been demonstrated to consume Aspergillus spp, and Penicillium spp. in the laboratory (Molva et al., 2019). Therefore, it is highly probable they also consume these fungi in the home, and may utilise Glu enzymes to digest these fungi as they do for $S$. cerevisiae, thus explaining unexpected presence of Glu1 and Glu2 in house dust. Our previous proteomic characterisation of HD and SM identified distinct parallels in the types of proteins identified in both of these conditions (Waldron et al., 2019). This data further demonstrates the utility of laboratory-based models for understanding the wildtype proteome of $D$. pteronyssinus.

Overall, our data infers that Glu1, Glu2 and Glu3 are digestive enzymes involved in HDM digestion of fungi. D. pteronyssinus contains an additional Glu protein, Glu2, which may confer a specialisation for mycophagy over other HDMs. Both Glu1 and Glu2 exhibit hydrolytic activity against $\beta-1,3$ glucans a major structural component of fungal cell walls and were increased in abundance in the SM of $D$. pteronyssinus airmid fed a diet containing $S$. cerevisiae. Basal expression and excretion of Glu1 and Glu2, in D. pteronyssinus airmid reared on a diet free of yeast, indicate they are produced in response to common microbes copresent in laboratory cultures. The identification of $\beta-1,3$ glucanase activity, and positive identification of Glu1 and Glu2 in HD provides compelling evidence that these are important enzymes utilised by $D$. pteronyssinus in both the laboratory and wildtype setting, for the digestion of fungi.

\section{Acknowledgments}

RW is a recipient of an Irish Research Council Enterprise Partnership Scheme Scholar (EPSPG/2014/64). JM is funded by a postgraduate scholarship from the Irish Research Council, Government of Ireland (GOIPG/2016/1112). Mass spectrometry facilities were funded by a Science Foundation Ireland infrastructure award to SD (SFI 12/RI/ 2346(3)). We acknowledge the DJEI/DES/SFI/HEA Irish Centre for High-End Computing (ICHEC) for the provision of computational facilities and support. This work was co-funded by airmid healthgroup ltd, Dublin, Ireland.

\section{Appendix A. Supplementary data}

Supplementary data to this article can be found online at https:// doi.org/10.1016/j.ibmb.2019.103242.

S1 Figure. Maximum Likelihood Phylogeny of Glu Homologs from Diverse Taxa. Bootstrap support values are shown at nodes. Bacterial, Fungal, Acariformes and other animals have their names highlighted with red, green, blue and purple text, respectively. Glu homologs are grouped in a single clade (highlighted with blue coloured branches) that also contains the majority of eukaryote homologs. Three additional Acariformes homologs (highlighted with purple branches) are grouped amongst bacterial species.

\section{References}

Aguilar-Uscanga, B., Francois, J.M., 2003. A study of the yeast cell wall composition and structure in response to growth conditions and mode of cultivation. Lett. Appl. Microbiol. 37, 268-274.

Altschul, S.F., Madden, T.L., Schaffer, A.A., Zhang, J., Zhang, Z., Miller, W., Lipman, D.J., 1997. Gapped BLAST and PSI-BLAST: a new generation of protein database search programs. Nucleic Acids Res. 25, 3389-3402.

Alvarez, T.M., Liberato, M.V., Cairo, J.P.L.F., Paixão, D.A.A., Campos, B.M., Ferreira, M.R., Almeida, R.F., Pereira, I.O., Bernardes, A., Ematsu, G.C.G., Chinaglia, M., Polikarpov, I., de Oliveira Neto, M., Squina, F.M., 2015. A novel member of GH16 family derived from sugarcane soil metagenome. Appl. Biochem. Biotechnol. 177, 304-317.

Barrero, R.A., Guerrero, F.D., Black, M., McCooke, J., Chapman, B., Schilkey, F., Perez de Leon, A.A., Miller, R.J., Bruns, S., Dobry, J., Mikhaylenko, G., Stormo, K., Bell, C., Tao, Q., Bogden, R., Moolhuijzen, P.M., Hunter, A., Bellgard, M.I., 2017. Gene-enriched draft genome of the cattle tick Rhipicephalus microplus: assembly by the hybrid Pacific Biosciences/Illumina approach enabled analysis of the highly repetitive genome. Int. J. Parasitol. 47, 569-583.

Bethke, P.C., Busse, J.C., 2008. Validation of a simple, colorimetric, microplate Assay using amplex red for the determination of glucose and sucrose in potato tubers and other vegetables. Am. J. Potato Res. 85, 414.

Bordas-Le Floch, V., Le Mignon, M., Bussieres, L., Jain, K., Martelet, A., Baron-Bodo, V., Nony, E., Mascarell, L., Moingeon, P., 2017. A combined transcriptome and proteome analysis extends the allergome of house dust mite Dermatophagoides species. PLoS One 12 , e0185830.

Bragatto, I., Genta, F.A., Ribeiro, A.F., Terra, W.R., Ferreira, C., 2010. Characterization of a $\beta$-1,3-glucanase active in the alkaline midgut of Spodoptera frugiperda larvae and its relation to $\beta$-glucan-binding proteins. Insect Biochem. Mol. Biol. 40, 861-872.

Brooks, C.R., Siebers, R., Crane, J., Noss, I., Wouters, I.M., Sander, I., Raulf-Heimsoth, M., Thorne, P.S., Metwali, N., Douwes, J., 2013. Measurement of beta-(1,3)-glucan in household dust samples using Limulus amebocyte assay and enzyme immunoassays: an inter-laboratory comparison. Environ. Sci. Process. Impacts 15, 405-411.

Burgess, S.T.G., Bartley, K., Marr, E.J., Wright, H.W., Weaver, R.J., Prickett, J.C., Hughes, M., Haldenby, S., Thi Le, P., Rombauts, S., Van Leeuwen, T., Van de Peer, Y., Nisbet, A.J., 2018. Draft Genome Assembly of the Sheep Scab Mite, $<$ span class = "namedcontent genus-species" id = "named-content-1" $>$ Psoroptes ovis $</$ span $>$ Genome Announc. 6.

Chan, T.F., Ji, K.M., Yim, A.K.Y., Liu, X.Y., Zhou, J.W., Li, R.Q., Yang, K.Y., Li, J., Li, M., Law, P.T.W., Wu, Y.L., Cai, Z.L., Qin, H., Bao, Y., Leung, R.K.K., Ng, P.K.S., Zou, J., Zhong, X.J., Ran, P.X., Zhong, N.S., Liu, Z.G., Tsui, S.K.W., 2015. The draft genome, transcriptome, and microbiome of Dermatophagoides farinae reveal a broad spectrum of dust mite allergens. J. Allergy Clin. Immunol. 135, 539-548.

Colloff, M.J., 2009. Dust Mites. CSIRO Publishing, Springer, Van Godewijckstraat 303311 GX Dordrecht The Netherlands.

Cornman, S.R., Schatz, M.C., Johnston, S.J., Chen, Y.P., Pettis, J., Hunt, G., Bourgeois, L., Elsik, C., Anderson, D., Grozinger, C.M., Evans, J.D., 2010. Genomic survey of the ectoparasitic mite Varroa destructor, a major pest of the honey bee Apis mellifera. BMC Genomics 11.

Darriba, D., Taboada, G.L., Doallo, R., Posada, D., 2011. ProtTest 3: fast selection of bestfit models of protein evolution. Bioinformatics 27, 1164-1165.

Deb, R., Shakib, F., Reid, K., Clark, H., 2007. Major house dust mite allergens Dermatophagoides pteronyssinus 1 and Dermatophagoides farinae 1 degrade and inactivate lung surfactant proteins A and D. J. Biol. Chem. 282, 36808-36819.

Dolan, Stephen K., Owens, Rebecca A., O'Keeffe, G., Hammel, S., Fitzpatrick, David A., Jones, Gary W., Doyle, S., 2014. Regulation of nonribosomal peptide synthesis: bisthiomethylation attenuates gliotoxin biosynthesis in Aspergillus fumigatus. Chem. Biol. 21, 999-1012.

Dong, X., Armstrong, S.D., Xia, D., Makepeace, B.L., Darby, A.C., Kadowaki, T., 2017. Draft genome of the honey bee ectoparasitic mite, Tropilaelaps mercedesae, is shaped by the parasitic life history. Gigascience 6, 1-17.

Duek, L., Kaufman, G., Palevsky, E., Berdicevsky, I., 2001. Mites in fungal cultures. Mycoses 44, 390-394.

Edgar, R.C., 2004. MUSCLE: multiple sequence alignment with high accuracy and high throughput. Nucleic Acids Res. 32, 1792-1797.

Erban, T., Hubert, J., 2008. Digestive function of lysozyme in synanthropic acaridid mites enables utilization of bacteria as a food source. Exp. Appl. Acarol. 44, 199-212.

Erban, T., Hubert, J., 2010. Determination of $\mathrm{pH}$ in regions of the midguts of acaridid mites. J. Insect Sci. 10 42-42.

Erban, T., Hubert, J., 2012. Digestive physiology of synanthrophic mites (Acari: Acaridida). SOAJ Entomol. Stud. 1-32.

Felsenstein, J., 1978. Cases in which parsimony or compatibility methods will be positively misleading. Syst. Zool. 27, 401-410.

Fesel, P.H., Zuccaro, A., 2016. $\beta$-glucan: crucial component of the fungal cell wall and elusive MAMP in plants. Fungal Genet. Biol. 90, 53-60.

Fitzpatrick, D.A., 2012. Horizontal gene transfer in fungi. FEMS Microbiol. Lett. 329, 1-8.

Gastebois, A., Fontaine, T., Latgé, J.-P., Mouyna, I., 2010. beta(1-3)Glucanosyltransferase Gel4p is essential for Aspergillus fumigatus. Eukaryot. Cell 9, 1294-1298.

Grbić, M., Van Leeuwen, T., Clark, R.M., Rombauts, S., Rouzé, P., Grbić, V., Osborne, E.J., Dermauw, W., Thi Ngoc, P.C., Ortego, F., Hernández-Crespo, P., Diaz, I., Martinez, M., Navajas, M., Sucena, É., Magalhães, S., Nagy, L., Pace, R.M., Djuranović, S., Smagghe, G., Iga, M., Christiaens, O., Veenstra, J.A., Ewer, J., Villalobos, R.M., Hutter, J.L., Hudson, S.D., Velez, M., Yi, S.V., Zeng, J., Pires-daSilva, A., Roch, F., Cazaux, M., Navarro, M., Zhurov, V., Acevedo, G., Bjelica, A., Fawcett, J.A., Bonnet, E., Martens, C., Baele, G., Wissler, L., Sanchez-Rodriguez, A., Tirry, L., Blais, C., 
Demeestere, K., Henz, S.R., Gregory, T.R., Mathieu, J., Verdon, L., Farinelli, L., Schmutz, J., Lindquist, E., Feyereisen, R., Van de Peer, Y., 2011. The genome of Tetranychus urticae reveals herbivorous pest adaptations. Nature 479, 487.

Gulia-Nuss, M., Nuss, A.B., Meyer, J.M., Sonenshine, D.E., Roe, R.M., Waterhouse, R.M., Sattelle, D.B., de la Fuente, J., Ribeiro, J.M., Megy, K., Thimmapuram, J., Miller, J.R., Walenz, B.P., Koren, S., Hostetler, J.B., Thiagarajan, M., Joardar, V.S., Hannick, L.I., Bidwell, S., Hammond, M.P., Young, S., Zeng, Q., Abrudan, J.L., Almeida, F.C., Ayllón, N., Bhide, K., Bissinger, B.W., Bonzon-Kulichenko, E., Buckingham, S.D., Caffrey, D.R., Caimano, M.J., Croset, V., Driscoll, T., Gilbert, D., Gillespie, J.J., Giraldo-Calderón, G.I., Grabowski, J.M., Jiang, D., Khalil, S.M.S., Kim, D., Kocan, K.M., Koči, J., Kuhn, R.J., Kurtti, T.J., Lees, K., Lang, E.G., Kennedy, R.C., Kwon, H., Perera, R., Qi, Y., Radolf, J.D., Sakamoto, J.M., Sánchez-Gracia, A., Severo, M.S., Silverman, N., Simo, L., Tojo, M., Tornador, C., Van Zee, J.P., Vázquez, J., Vieira, F.G., Villar, M., Wespiser, A.R., Yang, Y., Zhu, J., Arensburger, P., Pietrantonio, P.V., Barker, S.C., Shao, R., Zdobnov, E.M., Hauser, F., Grimmelikhuijzen, C.J.P., Park, Y., Rozas, J., Benton, R., Pedra, J.H.F., Nelson, D.R., Unger, M.F., Tubio, J.M.C., Tu, Z., Robertson, H.M., Shumway, M., Sutton, G., Wortman, J.R., Lawson, D., Wikel, S.K., Nene, V.M., Fraser, C.M., Collins, F.H., Birren, B., Nelson, K.E., Caler, E., Hill, C.A., 2016. Genomic insights into the Ixodes scapularis tick vector of Lyme disease. Nat. Commun. 7, 10507.

Jiggins, F.M., Palmer, W.J., 2015. Comparative genomics reveals the origins and diversity of arthropod immune systems. Mol. Biol. Evol. 32, 2111-2129.

Kaarakainen, P., Rintala, H., Vepsalainen, A., Hyvarinen, A., Nevalainen, A., Meklin, T., 2009. Microbial content of house dust samples determined with qPCR. Sci. Total Environ. 407, 4673-4680.

Kauffman, H.F., Tamm, M., Timmerman, J.A.B., Borger, P., 2006. House dust mite major allergens Der p 1 and Der p 5 activate human airway-derived epithelial cells by protease-dependent and protease-independent mechanisms. Clin. Mol. Allergy : CMA 4 5-5.

Klimov, P.B., O'Connor, B., 2013. Is permanent parasitism reversible?-critical evidence from early evolution of house dust mites. Syst. Biol. 62, 411-423.

Liu, X.Y., Yang, K.Y., Wang, M.Q., Kwok, J.S., Zeng, X., Yang, Z., Xiao, X.J., Lau, C.P., Li, Y., Huang, Z.M., Ba, J.G., Yim, A.K., Ouyang, C.Y., Ngai, S.M., Chan, T.F., Leung, E.L., Liu, L., Liu, Z.G., Tsui, S.K., 2018. High-quality assembly of Dermatophagoides pteronyssinus genome and transcriptome reveals a wide range of novel allergens. J. Allergy Clin. Immunol. 141, 2268-2271.

Maheswaran, D., Zeng, Y., Chan-Yeung, M., Scott, J., Osornio-Vargas, A., Becker, A.B., Kozyrskyj, A.L., 2014. Exposure to Beta-(1,3)-D-glucan in house dust at age 7-10 is associated with airway hyperresponsiveness and atopic asthma by age 11-14. PLoS One 9 e98878-e98878.

Martinez, J., Eraso, E., Palacios, R., Guisantes, J.A., 1999. Enzymatic analyses of house dust mite extracts from Dermatophagoides pteronyssinus and Dermatophagoides farinae (Acari: pyroglyphidae) during different phases of culture growth. J. Med. Entomol. 36, 370-375.

McCarthy, C.G., Fitzpatrick, D.A., 2016. Systematic search for evidence of interdomain horizontal gene transfer from prokaryotes to oomycete lineages. mSphere 1.

Molva, V., Bostlova, M., Nesvorna, M., Hubert, J., 2018. Do the microorganisms from laboratory culture spent growth medium affect house dust mite fitness and microbiome composition? Insect Sci. https://doi.org/10.1111/1744-7917.12636.

Molva, V., Nesvorna, M., Hubert, J., 2019. Feeding interactions between microorganisms and the house dust mites Dermatophagoides pteronyssinus and Dermatophagoides farinae (astigmata: pyroglyphidae). J. Med. Entomol. https://doi.org/10.1093/jme/ tjz089.

Moraes, C.d.S., Diaz-Albiter, H.M., Faria, M.d.V., Sant'Anna, M.R.V., Dillon, R.J., Genta, F.A., 2014. Expression pattern of glycoside hydrolase genes in Lutzomyia longipalpis reveals key enzymes involved in larval digestion. Front. Physiol. 5 276-276.

O'Connor, B.M., 1979. Evolutionary origins OF ASTIGMATID mites inhabiting stored products. In: Rodriguez, J.G. (Ed.), Recent Advances in Acarology. Academic Press, pp. 273-278.

O'Keeffe, G., Hammel, S., Owens, R.A., Keane, T.M., Fitzpatrick, D.A., Jones, G.W., Doyle, S., 2014. RNA-seq reveals the pan-transcriptomic impact of attenuating the gliotoxin self-protection mechanism in Aspergillus fumigatus. BMC Genomics 15, 894.

Pauchet, Y., Freitak, D., Heidel-Fischer, H.M., Heckel, D.G., Vogel, H., 2009. Immunity or digestion: glucanase activity in a glucan-binding protein family from Lepidoptera. J. Biol. Chem. 284, 2214-2224.

Price, M.N., Dehal, P.S., Arkin, A.P., 2010. FastTree 2-approximately maximum-likelihood trees for large alignments. PLoS One 5, e9490.

Randall, T.A., Mullikin, J.C., Mueller, G.A., 2018. The draft genome assembly of Dermatophagoides pteronyssinus supports identification of novel allergen isoforms in Dermatophagoides species. Int. Arch. Allergy Immunol. 175, 136-146.

Rider, S.D., Morgan, M.S., Arlian, L.G., 2015. Draft Genome of the Scabies Mite, vol. 8 Parasites \& Vectors.

Rider Jr., S.D., Morgan, M.S., Arlian, L.G., 2017. Allergen homologs in the Euroglyphus maynei draft genome. PLoS One 12, e0183535.

Rintala, H., Pitkaranta, M., Taubel, M., 2012. Microbial communities associated with house dust. Adv. Appl. Microbiol. 78, 75-120.

Sayers, E.W., Cavanaugh, M., Clark, K., Ostell, J., Pruitt, K.D., Karsch-Mizrachi, I., 2019. GenBank. Nucleic Acids Res. 47, D94-d99.

Schwager, E.E., Sharma, P.P., Clarke, T., Leite, D.J., Wierschin, T., Pechmann, M., Akiyama-Oda, Y., Esposito, L., Bechsgaard, J., Bilde, T., Buffry, A.D., Chao, H., Dinh, H., Doddapaneni, H., Dugan, S., Eibner, C., Extavour, C.G., Funch, P., Garb, J., Gonzalez, L.B., Gonzalez, V.L., Griffiths-Jones, S., Han, Y., Hayashi, C., Hilbrant, M., Hughes, D.S.T., Janssen, R., Lee, S.L., Maeso, I., Murali, S.C., Muzny, D.M., Nunes da Fonseca, R., Paese, C.L.B., Qu, J., Ronshaugen, M., Schomburg, C., Schonauer, A., Stollewerk, A., Torres-Oliva, M., Turetzek, N., Vanthournout, B., Werren, J.H., Wolff, C., Worley, K.C., Bucher, G., Gibbs, R.A., Coddington, J., Oda, H., Stanke, M., Ayoub, N.A., Prpic, N.M., Flot, J.F., Posnien, N., Richards, S., McGregor, A.P., 2017. The house spider genome reveals an ancient whole-genome duplication during arachnid evolution. BMC Biol. 15, 62.

Shevchenko, A., Tomas, H., Havli, J., Olsen, J.V., Mann, M., 2006. In-gel digestion for mass spectrometric characterization of proteins and proteomes. Nat. Protoc. 1, 2856-2860.

Song, J.M., Nam, K., Sun, Y.-U., Kang, M.H., Kim, C.-G., Kwon, S.-T., Lee, J., Lee, Y.-H., 2010. Molecular and biochemical characterizations of a novel arthropod endo- $\beta-1,3$ glucanase from the Antarctic springtail, Cryptopygus antarcticus, horizontally acquired from bacteria. Comp. Biochem. Physiol. B Biochem. Mol. Biol. 155, 403-412.

Sousa, A.C., Almeida, J.R., Pereira, C.C., Ramiro Pastorinho, M., Pereira, A.M., Nogueira, A.J., Taborda-Barata, L., Teixeira, J.P., Correia, A.C., Alves, A., 2014 Characterization of fungal communities in house dust samples collected from central Portugal-a preliminary survey. J. Toxicol. Environ. Health 77, 972-982.

Stamatakis, A., 2014. RAxML version 8: a tool for phylogenetic analysis and post-analysis of large phylogenies. Bioinformatics 30, 1312-1313.

Tang, V.H., Stewart, G.A., Chang, B.J., 2017. Dermatophagoides pteronyssinus lytFM encoding an NlpC/P60 endopeptidase is also present in mite-associated bacteria that express LytFM variants. FEBS Open Bio 7, 1267-1280.

van Bronswijk, J.E.M.H., 1973. Dermatophagoides pteronyssinus (trouessart, 1897) in mattress and floor dust in a temperate climate (Acari: pyroglyphidae). J. Med. Entomol. 10, 63-70.

Van Rinsum, J., Klis, F.M., van den Ende, H., 1991. Cell wall glucomannoproteins of Saccharomyces cerevisiae mnn9. Yeast 7, 717-726.

Waldron, R., McGowan, J., Gordon, N., McCarthy, C., Mitchell, E.B., Doyle, S., Fitzpatrick, D.A., 2017. Draft genome sequence of Dermatophagoides pteronyssinus, the european house dust mite. Genome Announc. 5 e00789-00717.

Waldron, R., McGowan, J., Gordon, N., McCarthy, C., Mitchell, E.B., Fitzpatrick, D.A., 2019. Proteome and allergenome of the European house dust mite Dermatophagoides pteronyssinus. PLoS One 14, e0216171.

Zock, J.P., Heinrich, J., Jarvis, D., Verlato, G., Norback, D., Plana, E., Sunyer, J., Chinn, S., Olivieri, M., Soon, A., Villani, S., Ponzio, M., Dahlman-Hoglund, A., Svanes, C., Luczynska, C., 2006. Distribution and determinants of house dust mite allergens in europe: the european community respiratory health survey II. J. Allergy Clin. Immunol. 118, 682-690. 